\title{
Sequencing and Timing of Strategic Responses after Industry Disruption: Evidence from Post-Deregulation Competition in the U.S. Railroad Industry
}

\author{
Michael L. Pettus \\ Transportation Consultant \\ matchpt606050@yahoo.com \\ Yasemin Y. Kor \\ Professor of Strategic Management \\ Judge Business School \\ University of Cambridge \\ Trumpington Street \\ Cambridge CB2 1AG \\ Cambridge, United Kingdom \\ y.kor@jbs.cam.ac.uk \\ Joseph T. Mahoney \\ Caterpillar Chair of Business \\ Professor of Strategy and Entrepreneurship \\ Director of Research \\ Department of Business Administration \\ 140C Wohlers Hall \\ 1206 South Sixth Street \\ Champaign, IL 61820 \\ josephm@,illinois.edu \\ Steven C. Michael \\ Professor of Business Administration \\ Department of Business Administration \\ 350 Wohlers Hall \\ 1206 South Sixth Street \\ Champaign, IL 61820 \\ smichael@uiuc.edu
}

Key words: Capability acquisition; Differential adaptability; Industry disruption; Regulatory shift (deregulation); Sequencing and timing of strategic responses 
Research on dynamic capabilities and strategic renewal suggests that firms must continuously invent and upgrade their capabilities to maintain competitive advantage and growth in a changing environment (Argyres, 1996; Verona and Ravasi, 2003; Zollo and Winter, 2002). Shifts in the competitive environment can be triggered by new technology, supply-side shocks, changing customer preferences, and industry deregulation and re-regulation - all of which require strategic adaptation and renewal of competencies (Augier and Teece, 2009; Eisenhardt and Martin, 2000; Tripsas, 2007). Sudden escalations of competitive pressures and customer expectations require new firm-level competencies (Helfat and Peteraf, 2003; Mahoney and McGahan, 2007). Lack of firm-level adaptive capability to re-align with industry conditions can lead to firm failure (Capron and Mitchell, 1998; Helfat et al., 2009).

In responding to a major shift in the competitive environment, firms often differ in their strategic choices. Specifically, firms may differ in the sequencing of their strategic responses to changes over time. Exemplary contributions in strategy highlight the importance of examining firms' sequencing or patterns of strategic choices and initiatives (e.g., Burgelman, 1983; Mintzberg and Waters, 1982; Penrose, 1960). However, the empirical research in strategy typically continues to take a discrete approach by focusing on a single competitive move or strategic choice at a point in time (Langley, et al., 2013). Examining the sequencing of specific strategic responses over time is important because in an increasingly competitive environment it is the firm's series of consecutive competitive moves that shapes its long-term ability to survive and prosper. Our understanding of competitive dynamics is particularly lacking concerning the consequences of strategic responses after significant industry deregulation where a once highlyconstrained managerial discretion is broadened due to the lifting of controls on pricing, entry-exit, and expansion-acquisition. Thus, our research study investigates the consequences of the sequencing of firms' strategic responses following a disruptive deregulation that ended an extended time-period of reduced managerial discretion and opened substantial strategic options.

After deregulation, incumbent firms participating in time-based competition must acquire new competencies to adaptively respond to their rivals within this new competitive landscape. Cooperative 
strategies such as acquisitions can enable firms to quickly access critical resources and to reconfigure their resource combinations to re-align with new industry conditions brought about by these shifts (Chen et al., 2012; Garrette et al., 2009; Pacheco-de-Almeida and Zemsky, 2007). Yet firms often differ in the timing of such initiatives (Carow et al., 2004; Haleblian et al., 2012). The timing of acquisitions as strategic responses can shape the adaptive ability following deregulation, because there is a limited set of acquisition targets (Yip, 1982), and only some of these target firms offer a strategic fit (Mahoney and Pandian, 1992). Thus, to develop a better understanding of competition in the aftermath of a major industry deregulation and what sets apart survivors from failures, it is important to examine both the sequencing and timing of strategic responses by industry firms in the post-deregulation period.

To address this research gap, we examine the sequencing and timing of strategic responses by Class I U.S. railroad companies during the post-deregulation period of 1980 through 2003. This timeperiod begins with the passage of the 1980 Staggers Rail Act, which ended an almost century-long period of regulation by the Interstate Commerce Commission (Winston, et al., 1990). In this time-period, "not only did regulators permit rail executives greater freedom to abandon unprofitable segments and acquire new lines, they also allowed rail leaders to circumvent regulations that restricted rail ownership of other modes of transportation. As a result, railroad officials gained access to markets that only motor and water carriers could exploit. The markets that railroads served suddenly increased" (Burns, 1998: 174-175). The post-deregulation period was characterized by competitive acquisitions and industry consolidation. Of the total of 40 Class I railroads that operated in the United States prior to deregulation, only 9 of these railroads survived as an independent legal entity until 2003 when the Surface Transportation Board implemented a moratorium on railroad acquisitions (Berman, 2010).

In the current study, we seek to make at least three contributions to the research literatures on strategic renewal and competitive strategy. First, our study's unique focus on the sequencing of response strategies enables us to demonstrate that it is not the single strategic choice or response per se, but the sequencing of consecutive strategic responses that drives incumbent firms' adaptation and survival in the 
aftermath of a significant shift in the industry. Firms achieve higher profitability when they give attention to both sequencing and the timing of these adaptive moves in relation to the pioneers in the industry.

Second, we demonstrate that how incumbent firms specifically modify their resource base after deregulation is critical for their survival. Reconfiguration of a firm's resource base under rapid change is far from fully understood, especially in terms of the sequencing of moves for competency development in time-based competition (Kor and Mahoney, 2005; Walker et al., 2002). We find that firms that grew their competencies strategically showed a positive differential adaptability after deregulation. These survivors were at a unique juxtaposition of responding to demand-side pressures (Priem et al., 2012; Shah and Tripsas, 2007) and choosing a path of new capability acquisition in efficient and effective ways. These firms not only responded to new customer demands and competitive pressures, but also chose a superior sequencing of the strategic moves of leveraging and stretching firm-level capabilities.

Third, we show the critical role of acquisitions in strategic renewal after industry disruption. Research reveals that acquisitions often yield negative financial results for acquirers (King et al., 2004) where performance is captured by abnormal stock market returns following acquisition announcements (Zollo and Meier, 2008). However, by focusing on a single acquisition at a point in time, it is difficult to understand what happens to the population of industry firms, and whether incumbents in the industry survive an important disruption in the competitive environment. We show that the surviving firms possessed the foresight to view the industry disruption not only as a threat, but also as an opportunity, and that each of their acquisition choices was part of a longer-term strategic vision. If acquisitions were examined as independent events, the big picture would have been lost, and the value creation and capture of these strategic moves would not be fully considered (McGrath, 1999; Smit and Moraitis, 2010).

\section{INDUSTRY DISRUPTION AND SEQUENCING OF STRATEGIC RESPONSES}

The empirical research in strategy has typically followed a discrete approach by focusing on a single competitive move or strategic choice at a point in time (Langley et al., 2013). We are now beginning to see a change to this approach where research studies consider multiple strategic choices or 
responses of firms (Carow et al., 2004; Haleblian et al., 2012; Shi and Prescott, 2011, 2012). An exemplar is the acquisition and alliance research where studies now investigate the experience of firms in acquisitions (or alliances) over time, and examine the effects of acquisition experience, rate, and the variability of rate on firm performance (Haleblian and Finkelstein, 1999; Laamanen and Keil, 2008). Such research enables us to better understand how firms develop or improve their acquisition capabilities.

Several empirical studies in this domain examine the sequencing of acquisitions and alliances of firms. Shi and Prescott (2011) identify different sequential patterns that firms followed in their acquisition and alliances. The study focuses on the specialty pharmaceuticals segment, which saw the emergence of new business opportunities in relation to the U.S. Orphan Drug Act (1984), and finds that firms with a predictable pattern (i.e., a consistent rhythm) of acquisitions and alliances achieve the highest levels of economic profitability (Tobin's Q). In the same industry, Shi and Prescott (2012) further show that firms perform better when the rhythm (pacing) of their alliance activity follows those of their rivals.

Klarner and Raisch (2013) investigate European insurance firms' strategic response patterns (entry into a new business segment; entry into a new country; and refocusing) in a time-period of industry deregulation that allowed firms to compete across all European markets. The study shows that firms with regular change rhythms with regularly spaced intervals outperform firms that have irregular change rhythms. Irregular rhythms involved: frequent changes followed by short stability periods; long stability periods interrupted by short periods of change; or irregularly switching between change and stability.

These recent studies enable a more complete view in understanding firm's strategic responses over time, and are instrumental in highlighting the role of strategic response frequency and rhythms in driving a firm's success. In the broader literature, however, several weaknesses remain. For example, many studies in acquisition research domain fail to connect a firm's acquisition experience to the content of acquisitions, i.e., what the acquisition entails and why it was conducted in the first place (specific purpose). Acquisitions as a mode of strategic response are not examined as part of the firm's existing and evolving corporate strategy. Likewise, the competitive environment of strategic responses is relegated to 
the background and reduced to control variables. Such an approach is problematic when the change in the environment calls for a specific response in strategy (not just any change). Further, the inter-linkages between the specific responses as a path of strategic responses are not identified and examined. Even though the studies consider that firms conducted multiple responses (e.g., frequency and rhythm of acquisitions), we do not fully understand how these responses fit with the firm's corporate and competitive strategy trajectories and the industry evolution. We are missing the big picture.

Acknowledging these weaknesses, there have been calls in the literature for future research that reveals the content of a firm's strategic response program (e.g., acquisition program). For example, Laamanen and Keil suggest that "we regard acquisition program content characteristics, such as the relatedness or complementarity of different transactions or their fit with the overall strategic goal pursued in the acquisition program, important for further advancing the understanding of the performance of acquisition programs" (2008: 670). The current study addresses these calls in the research literature by linking content and sequencing of strategic responses to the evolution of the firm's corporate strategy.

Our study brings all three of these elements to the foreground of research: (1) firms' evolving corporate strategy; (2) the competitive environment in which firms' strategic responses are embedded; and (3) the sequential linkages among incumbent firms' responses. Our research study is distinct from past studies in considering firms' strategic responses on a continuum where one strategic response prepares the firm for the next response as a major industry disruption unfolds. Here, the firm's strategic response combines the change in corporate-level growth strategy (Ansoff, 1965) and the strategic choice of mode of growth (internal growth vs. acquisitions), and these choices shape the competitive positioning of the firm in the new environment (e.g., cost-effectiveness and differentiation).

In pursuing our research objective, we focus on the sequencing of incumbent firms' strategic responses in the aftermath of an industry disruption. Disruptions in the firm's environment can redefine the competitive landscape in which the firm operates and can make a firm's specific competencies less relevant, if not obsolete. Such disruptions may be driven by a range of factors including breakthrough 
technology, supply-side shocks, shifts in customer demand and preferences, and new industry regulation or deregulation (Kim and Prescott, 2005; Tripsas, 2007). For example, industry deregulation can trigger a chain of adaptive responses by at least some firms that alter the competitive landscape (Peteraf and Reed, 2007; Reger et al., 1992). The effects of deregulation usually unfold over time but can result in a new set of competitive rules of the game. To appreciate the magnitude of change that deregulation can cause, one must understand the kinds of restrictions regulations can place on industry firms (Reger et al., 1992; Spulber, 1989). Regulated firms are typically restricted in the range of products and services they can offer and the scope of the geographic market they can serve (Smith and Grimm, 1987). When market entry- and exit-decisions are controlled by regulations, competition is restricted in the entire market or certain geographical regions (Mahon and Murray, 1981). It is not uncommon for such controls to be combined with price regulation, where a governmental agency plays a critical role in the setting of rates for different product and service categories (Guthrie et al., 1991). Due to restrictions on market entry, firms cannot always take advantage of emerging opportunities to leverage their competencies (Penrose, 1959; Reger et al., 1992). Due to market exit restrictions, firms may be forced to operate in markets despite low or negative economic returns (Jayaratne and Strahan, 1998). Firms' inability to change their pricing strategy freely in a regulated industry can be a competitive disadvantage when these firms face rivalry from substitute products and services. Thus, heavily regulated firms may suffer from operational inefficiencies, poor capital utilization, and lack of managerial experience in competing in environments where higher managerial discretion and flexibility are allowed (Phillips, 1991; Spulber, 1989).

Following a major industry deregulation -- and using Ansoff's (1965) framework -- firms have four growth-based response options in relation to their corporate strategy: (1) stay in the current market (market penetration); (2) grow into new markets using the same products (market development); (3) diversify into other (related) transportation modes or international markets (product or international diversification); or (4) diversify into new markets with new products (i.e., unrelated diversification). The unrelated diversification option is often undesirable (and was not chosen by any of the railroads); thus, we 
do not consider it further in this study. Beyond the first option of market penetration, of the other two strategic response options, we first provide the rationale for why it is better for firms to switch from their status quo growth strategy to market development strategy, (i.e., expand in the railroad industry nationally), and why it would be a mistake for firms to diversify into other transportation modes or international markets from the beginning. Then, we differentiate between product diversification and international diversification, and provide the reasoning for why there is value to be gained by first pursuing a product diversification strategy that is followed by international diversification. ${ }^{1}$

A major industry deregulation represents a research opportunity to investigate incumbents' strategic renewal efforts as they can grow in new directions (Wiggins and Ruefli, 2002). However, before venturing into uncharted territories, these firms first must strengthen their core competencies and overcome their inherited weaknesses from the regulation era. Firms transitioning out of a regulatory regime often suffer from operational and scale-based inefficiencies that put them at a cost disadvantage. Under market entry and exit restrictions, firms accumulate under-utilized assets and redundancies in their operations (Winston et al., 1990). Such inefficiencies can be especially damaging when firms start to compete on the basis of price. As industry players will attempt to differentiate themselves also through higher quality of products and services, customer expectations are likely to rise along many dimensions. Thus, recalibration of incumbent firms' competencies in their main business domain is essential.

Recalibration of the existing competencies in a significantly deregulated environment can be accomplished with a market development strategy (Ansoff, 1965) where a firm provides its products and services to new markets (e.g., expansion of the railroad network). Combining the market development strategy with acquisitions enables firms to eliminate inefficiencies and capture new economies quickly.

\footnotetext{
${ }^{1}$ Here we focus on how the firm's choice of the corporate strategy is combined with the mode of strategy implementation, which was shaped by the competitive environment. As soon as some firms began to utilize acquisitions as a critical strategic tool to swiftly acquire new competencies and re-organize their business portfolios (e.g., geographical expansion in the national network), the speed and intensity of competition increased. The fact that the pool of suitable acquisition candidates was fixed and yet shrinking continuously further added to the intensity of this time-based competition.
} 
When a focal railroad acquires another railroad in the same region, it achieves savings by eliminating redundancies where rail operations overlap. These efficiencies are vital to the ability to attain a more cost- and price-competitive position vis-à-vis rivals. With the combined resources, the new firm will be in a stronger position to invest in new technologies (e.g., railroad computerized signaling and scheduling technologies to improve service efficiency and timeliness) that place the firm ahead of its rivals (Kim and Finkelstein, 2009; Lee and Lieberman, 2010). Railroads also acquired other railroads with tracks contiguous to theirs, which allowed geographical expansion of their lines. Acquisition of a rival railroad in an adjacent market gives the firm the ability to differentiate itself through an extended geographical service where clients use the one service provider to ship goods across multiple regions (Kor and Leblebici, 2005). This combination of market development and acquisition strategy enables firms to capture scale and geographical economies (Ansoff, 1965; Chandler, 1990) without adding to the existing (excess) capacity and rivalry in a market (Caves and Porter, 1977; Rumelt, 1984).

Despite the urgency to revitalize capabilities following industry disruption, some incumbents may continue their pre-deregulation growth strategy - market penetration via internal growth. This strategy will fall short of benefits from market development via acquisition strategy for two main reasons. First, the acquisition of a rival player allows for increased cost savings and efficiencies (e.g., elimination of redundant tracks) than a player can achieve in isolation (by eliminating its own under-utilized tracks). By pooling the resources of two companies, a firm would be in a stronger position to invest in new technology that increases the efficiency and reliability of its services, which serve as a differentiator. Second, the acquisition of a competitor with operations in different geographical region gives immediate access to a new customer base whereas setting up new operations and developing a new client base can take years to achieve.

Therefore, as an initial response strategy following a major deregulation, pursuing a market development strategy via acquisitions offers value creation and capture opportunities via inefficiency reduction and fast-paced differentiation (Garrette et al., 2009; Poppo and Zenger, 1998). Consequently, 
those firms that make the transition sooner from their status quo (pre-deregulation) market penetration strategy to market development via same industry acquisitions will be in a better position to survive in the newly defined environment compared with firms that make this transition later:

Hypothesis 1: Following a major deregulation, incumbent firms that make the transition sooner from the status quo market penetration strategy via internal growth to a market development strategy via same industry acquisitions will survive longer than firms that make this transition later.

The regulatory restrictions on market entry and exit choices prevent firms from systematically exploring diversification opportunities. Even when they can diversify, due to inefficiencies in their primary resource base, these firms are not well positioned to leverage their competencies through diversification. Yet, once deregulated firms eliminate their inefficiencies and calibrate their competencies in the primary market domain, they are prepared to undertake a related diversification strategy. The efficiencies captured and competencies developed through same industry acquisitions provide these deregulated firms the essential financial and managerial resources (slack) to successfully enter new (related) business domains (Chandler, 1990; Penrose, 1959; Teece, 1982).

In the competitive landscape of a deregulated industry, related diversification enables firms to respond to new customer demands. By offering a broader range of complementary (or substitute) products, a firm can become more attractive to its customers (Schilling, 2002). Customer-driven diversification takes advantage of demand-side complementarities, where having multiple (related) products increases firm's attractiveness to customers and their willingness to pay a premium (Schmidt and Keil, 2013). This type of competitive diversification strategy is observed in many industries, including: professional service firms (e.g., law firms providing legal service in multiple specialty areas to meet demands of large corporations), the computing industry (e.g., firms providing hardware products along with services such as solutions and cloud storage for clients), and the online vacation planning industry (providing consumers with the ability to book flights, hotels, cars, and vacation rentals using one portal). Firms that are among the first movers in a competitive diversification strategy can differentiate 
themselves by offering customers a one-stop shopping experience, which reduces customers' search and transaction costs (Priem, 2007). These firms also build reputation, relational capital, and experience-based advantages in delivery of complementary services.

Related diversification increases the likelihood of success after the first step of same industry expansion via acquisitions, as the efficiencies and stronger market position created in the first step allows the incumbent firm to underwrite the risk of expanding into a new area, which involves learning and new capability acquisition. Like the first step, pursuing related diversification through collaborative strategies such as acquisitions is the preferred choice, because it ensures speedy entry into this related business domain where the firm's new exchange partner has complementary resources (Kaul, 2012; Lee and Lieberman, 2010). After deregulation, the bar rises in customer expectations of quality, efficiency, and the integration of products and services. These expectations can be effectively met in a timely fashion if the firm pursues acquisitions or partnerships that help achieve presence in multiple related business domains. In an environment where there is urgency for developing new competencies, the set of opportunities and partners can shrink quickly due to preemption by early movers (Capron et al., 1998; Haleblian et al., 2012). Thus, timely transition from first to second strategic response matters once the industry pioneers initiate the second transition.

Hypothesis 2: Post deregulation, incumbent firms that make the transition from market development strategy to product diversification strategy sooner will survive longer than firms that make the transition later.

The third step for the growth and revitalization of the incumbent firms in the post-deregulation period involves expansion into international markets, which generates further scale and scope economies (Chandler, 1990; Johanson and Vahlne, 1977, 2009; Silverman, 1999). International growth enables the leveraging of existing competencies, including a firm's brand name and reputation, technology assets, and in some cases manufacturing and distribution capabilities. In business-to-business transactions, international growth creates customer responsiveness by enabling corporate customers to use the same business partners (e.g., suppliers or distributors) in multiple markets. Large firms pursuing international 
diversification expect their suppliers/distributors to follow them into new terrains (Hitt et al., 2006a). Serving these global customers internationally increases the depth of the relationship and results in stronger relational (client-specific) capital with them. Firms that fail to build an international presence may struggle to keep their large corporate customers. Loss of such (global) clients can diminish firms' capacity utilization and scale and scope economies, and thereby endanger their survival.

Internationalization can be demanding on managers, because it often involves new capability acquisition. Given institutional differences in legal, political, and economic systems and unique business practices in different countries (Aguilera and Jackson, 2003; Kostova et al., 2008), experience-based advantages are valuable internationally. Pioneering industry firms that go overseas have an early start in building systems and structures to operate in specific foreign markets. Thus, there is value in achieving international diversification through cooperative strategies such as acquisitions, which provide the element of speedy market entry and access to resources and competencies needed in this new domain (Markides and Ittner, 1994; Phene et al., 2012). Early acquisitions allow preemption because there is a finite pool of host-country firms with the necessary set of capabilities. Finding the right exchange partners is precursor in developing reputation and competency ahead of others. As early acquisitions shrink the pool of desirable foreign partners, it becomes increasingly difficult for non-responsive firms to embark on an international growth strategy.

Those firms that completed the first two steps (captured by $\mathrm{H} 1$ and $\mathrm{H} 2$ ) are likely to have a stronger resource base and market position in their primary market, and a broader portfolio of related products to offer in new markets - and these two steps provide these firms with a wide range of competencies that can be leveraged during international diversification (Hitt et al., 2006b). Asset stocks and financial and managerial slack built during the first two steps enable firms to make new investments and buffer the expected initial losses in foreign markets. The underpinning configuration of competencies that support diversified product offerings also makes firms economically attractive to foreign partners (Hitt et al., 2006a). Therefore, we predict that by transitioning into international diversification as the next 
step of their competitive strategy, firms can achieve better customer responsiveness, and thus, survive longer in the new environment.

Hypothesis 3: Post deregulation, incumbent firms that make the transition from product diversification strategy to international diversification strategy sooner will survive longer than firms that make the transition later.

\section{TIMING OF COMPETITIVE MOVES AND PERFORMANCE OUTCOMES}

Next, we consider the consequences of incumbents deviating from the superior path for an extended time-period. Even though the key changes in the post-deregulation business landscape are observable to all firms, firms differ in how they interpret these changes and their implications (Alvarez and Busenitz, 2001; Kor et al., 2007; Penrose, 1959). Maintaining current routines may stem from managerial risk aversion to new growth strategies or a misperception that the firm can survive this environmental shift by merely exploiting existing business domains (Barr et al., 1992; Nelson and Winter, 1982). Managers may also underestimate the speed at which a new set of industry strategic factors will emerge and dominate. In this environment, willingness and readiness of certain firms to move forward will set them apart as first movers in the industry (Chen, 1996; Hambrick et al., 1996).

First-mover advantages can be effective under specific industry conditions. In newly created industries or product categories, first movers can gain technological leadership, obtain valuable assets, create customer-switching costs, or even shape customer preferences (Lieberman and Montgomery, 1988; Thomas, 1996). In cross-industry samples, empirical research shows strong first-mover advantages for consumer brands (Urban et al., 1986), consumer goods companies (Robinson and Fornell, 1985), industrial goods companies (Robinson, 1988), and markets with network effects (Schilling, 2002).

First-mover advantages can be critical in a deregulated industry environment as early attempts for market expansion (in the existing, related, and international markets) can be imperative to create a differentiated market position ahead of others. Once the market entry and exit restrictions are removed, there is time-based competition to enter lucrative market segments, to establish relationships with key customers, and to leverage efficiency and competency gains into competitive pricing and resource bases 
for further growth. In pursuing these goals, cooperative strategies provide firms with the advantage of speed, but there is a time-based competition in finding the right exchange partners with desirable complementary assets (Carow et al., 2004, Haleblian et al., 2012; Teece, 1986).

Timing of these sequential moves matters because it impacts the ability of firms to make these investments in their competence domains (Ghemawat, 1991; Rumelt et al., 1991; Shi and Prescott, 2011). Over time, attractive market segments and positions become entrenched (as firms build reputation and competencies as isolating mechanisms) and desirable collaboration candidates may no longer be available (Smit and Moraitis, 2010). Being late to making certain competitive moves for an extended time-period can cause firms to develop a competitive disadvantage. Based on this reasoning our final hypotheses are:

Hypothesis 4a: At any given time, deviation from the superior strategic response will be associated with lower performance in that time-period.

Hypothesis 4b: $\quad$ The longer time an incumbent firm takes to correct its strategy, the lower its performance will be.

Hypothesis 4c: $\quad$ The longer the cumulative deviation from the superior path (i.e., total time spent with alternative choices), the bigger the negative impact on firm performance.

\section{METHODS}

\section{Data and variables}

This study examines the deregulated US railroad industry from 1980 until 2003 as the postderegulation period. Forty major railroads (termed class I) began the period at the time of deregulation in 1980. Health and efficiency of the railroad industry have critical effects on the competitiveness of key industries such as the energy industry (transportation of coal, LNG, and petroleum), the agriculture and food manufacturing industry (bulk grain), the automobile industry (car parts and finished cars), and the chemical industry (bulk chemical), as well as the rest of the economy due to its cascading effects of energy and food prices. We constructed a longitudinal dataset by utilizing information from the Association of American Railroads annual reports, firm annual and $10 \mathrm{~K}$ reports, and key industry 
informants. Industry and annual reports were used to capture changes in corporate strategy over two decades (Barr et al., 1992, Miller and Friesen, 1984).

The dependent variable for Hypotheses 1-3 is the length of survival in years. The dependent variable for Hypotheses 4a-c is annual firm financial performance, which is measured as return on equity (ROE). ROE captures the rate of return on the book value of shareholders' total investment in the firm, and measures the firm's success in creating shareholder value (Brealey et al., 2009). ROE has been the key performance indicator in empirical studies of the railroad industry (Smith and Grimm, 1987).

Regarding strategic response variables (H1-H3), we consulted with industry experts to classify the strategic response of each railroad firm for each year of the study. Because examining strategic changes in firms requires familiarity with organizations over time, industry experts are a useful source of information (Van de Ven, 2007; Zahra and Pearce 1990). Four industry experts who had extensive managerial experience in the industry independently classified each firm's growth choices for every year. The experts agreed in the clear majority of the cases; disagreement was very rare ( 5 cases). In these cases, the classification to which three of the four agreed was used. Table 1 shows the categories used by the industry experts to classify firms' strategy (column 1) and how they are mapped to the theoretical constructs (column 2). We used the methodology in previous research to categorize acquisitions as same industry acquisition or related industry acquisition (Chang and Singh 1999, Chatterjee 1990). If a firm acquired another railroad company, it was classified as same industry acquisition (SIC 4221 ). ${ }^{2}$ If the acquisition was in the same 2-digit SIC code (4200 - transportation industry), we classified an acquisition as related diversification. Entry into in a different 2-digit SIC would be classified as unrelated diversification although railroad firms did not venture outside of the transportation industry. Our theory focuses on survival as an independent entity in the post-deregulation environment, which is widely presumed as the first and most important goal in strategy. When a firm is eliminated, it fails to satisfy the

\footnotetext{
${ }^{2}$ The main mode of collaboration was acquisition. The fraction of firm-years following an acquisition strategy is $78 \%$. Alliances were combined with acquisitions as they both gave the firm the advantage of speed in entry.
} 
fundamental legal existence as a requirement of survival (Richard et al., 2009; Silverman et al., 1997); thus, being acquired and bankruptcy were pooled for the survival analysis. However, our results are robust to separating acquired and bankrupt firms, which we explain in the following section. ${ }^{3}$

Insert Table 1 about here

\section{ANALYSIS AND RESULTS}

\section{Survival effects of sequencing of resource acquisition strategies (Hypotheses 1-3)}

Forty railroad firms start the period in 1980, and one failed that year. We analyzed 39 firms, which were observed anywhere from 1 to 22 times. The clear majority of the firms did not survive the time-period as a stand-alone legal entity (31 out of 40 firms), and thus the panel is unbalanced.

All firms start with a strategy of market penetration in the regulated period. Starting in 1981, firms could choose among four strategies: market penetration (status quo same market internal growth), market development, product diversification, and related international diversification. Firms differed in whether the firm made the step to the next strategy and in how long they followed that strategy. A graphical representation of the strategies and the sequence is found in Figure 1. To explain the first node as an example, 39 firms faced the choice of whether to engage in market development via acquisitions: 23 decided yes and 16 decided no. Each railroad chose whether to move further up the sequence of strategies or to remain at its current strategy. ${ }^{4}$

\footnotetext{
${ }^{3}$ Acquisitions resulted in some negative consequences for certain stakeholders. Because railroad firms were looking to capture efficiencies, target firm employees were subject to significant layoffs and early retirement (Winston et al., 1990). Retiring tracks in low-volume lines reduced the bargaining power of some customers. Shipping rates were lower than pre-deregulation rates, but for captive customers the rates were significantly higher. In areas where tracks were retired or completely abandoned due to low freight volume, the surrounding communities were adversely affected.

${ }^{4}$ Each railroad could have chosen market development, product development, or international diversification. However, due to the sequential development of capabilities in this environment, railroads considered a common sequence of corporate strategy. The Krushal Goodman test introduced by Pelz (1985) corroborates this pattern as an ordered sequence.
} 
Insert Figure 1 about here

As a test of Hypotheses 1-3 (the sequencing of strategies), we statistically compared the length of survival between firms that followed the hypothesized superior path and those that did not at every step of the growth path. We use parametric (t-tests for comparison of means) and non-parametric methods (Wilcoxon Rank Test) to compare the duration of survival in years between firms that followed the hypothesized effective path and those that did not (Cooksey, 2007). These results are reported in Table 2. The initial panel of the Table reports the descriptive statistics of survival. In the second panel, we compare the mean length of survival for firms that followed the first hypothesized step (switched from market penetration to market development), and compared with those that stayed with the status quo market penetration. Firms that took the first step to market development had a higher survival time, more than twice longer (13.74 years versus 5.06 years), than those that remained in market penetration. The difference is statistically significant with either parametric or non-parametric methods, corroborating Hypothesis 1. Similarly, we compared firms that took the second step (from market development to product diversification) to firms that remained in market development. In other words, conditional upon taking the first step, we examined if firms that took the second step survive longer and found that they did. ${ }^{5}$ Firms making the second step survived 18 years while firms that didn't survived 5.75 years. The difference is statistically significant in both tests, and thus, Hypothesis 2 is supported.

Next, we compared firms that took the third step (from product diversification to international diversification) to firms that remained in product diversification. Firms making the third step survived 22 years, while firms that did not, survived 13.43 years, corroborating Hypothesis 3. Thus, in each transition or step above, railroad firms following the superior path survived longer than those that did not. ${ }^{6}$

\footnotetext{
${ }^{5}$ We note that the conditional test that we use is a stronger test than the unconditional test.

${ }^{6}$ As a robustness check, we examined whether the comparative analysis differs based upon whether firms filed for bankruptcy or were acquired. This robustness test is only relevant at the first step because only at this step
} 
In summary, eight of the longest survivors (out of the 9 survivors) followed the sequence (optimal path) hypothesized here, but there were alternative paths as shown in Figure 1. The next group of longsurvivors (consisting of the $9^{\text {th }}$ surviving firm and a number of long-surviving but ultimately acquired firms) followed a second pattern: same industry (internal) growth for an extended time-period, followed by same industry growth via acquisition (i.e., taking the hypothesized first step after a long lag), followed by same industry growth via domestic strategic alliance (i.e., repeating first step with an alliance), and then product diversification via strategic alliances (i.e., taking the second step via alliances). Nonsurviving firms in this group waited a substantial amount of time before pursuing market development and product diversification strategies, and never engaged in international expansion. We note that every non-survivor failed to make at least one of the transitions. Further robustness tests were done in Appendix A (at the end of the paper) where we controlled for potential endogeneity of the strategy. These tests confirmed the results provided here for Hypotheses 1-3.

Insert Table 2 about here

\section{Performance effects of superior response path and timing effects $(\mathrm{H} 4 \mathrm{a}-4 \mathrm{c})$}

Two descriptive and correlations tables were created for the next two sets of regressions we provide in the paper. For Hypotheses 4a-4c, we have taken the timing of our superior strategic response to be when the first railroad makes the hypothesized transition onto the growth path — a first-mover strategy. Based on our developed theory, as soon as one firm is observed following market development, it is wise for other firms to move to market development; as soon as one firm is observed following product

are there multiple observations in both bankruptcy and acquisition categories. No bankruptcies occurred at the second step stage, and only one occurred in the third step. At the first step, 23 firms that made the first switch from status quo strategy to market development strategy survived for 13.74 years on average. In comparison with that, 10 of the firms that stayed with the status quo strategy (and didn't make the switch) were acquired after surviving 5.16 years, and 6 of the firms that stayed with the status quo strategy (and didn't make the switch) went bankrupt after surviving 5 years. Among the firms that stayed with the status quo strategy, being acquired or going bankrupt had very similar durations of survival (5.16 and 5 years). Both types of firms lived much shorter than those that switched to market development strategy (5.06 versus 13.74 years). 
development strategy, it is time for others to switch to product development. Hypothesis 4a suggests that deviation from the hypothesized sequencing of strategic responses (at any step) will result in a penalty (the coefficient mu is negative). To test the effects of timing of growth choices and a penalty from the superior path (Hypotheses $4 b-c$ ), we calculated the length of time in years a firm follows the alternative paths (referred to as deviation) and the cumulative number of deviations the firm makes over the entire twenty-year period of observation. The cumulative deviation index increases by one when the market first mover's strategic response (step) changes but the firm stays the course in that year, and also by one if the firm stays off the superior response path.

To test Hypotheses $4 \mathrm{a}-4 \mathrm{c}$, we use the partial adjustment model, which is often employed in economics to capture costly adjustment over time (Greene 2003), such as modeling of royalty rates and franchise fees (e.g., Lafontaine and Shaw 1999). The key advantage of this model is that it allows us to embed our test of growth sequences into an optimization model. We start with a formulation of the performance determined by following the superior strategy:

$$
P^{*}(i, t)=\mathrm{A}\left(\mathrm{S}_{(i, t)}-\mathrm{S}_{(i, t)}\right)
$$

Here, $\mathrm{S}_{(i, t)}$ is the superior strategy and $\mathrm{S}_{(i, t)}$ is the strategy followed by firm i in year t. $P^{*}(i, t)$ is the performance of a firm, expressed as a function of whether it is following the superior growth path at a given time. The model posits that firms choose their growth path, but these firms cannot modify it instantaneously. As modeled below, the firm faces adjustment costs (Lafontaine and Shaw, 1999):

$$
\operatorname{Cost}\left(P_{(i, t)}\right)=\alpha\left(P_{(i, t)}-P^{*}{ }_{(i, t)}\right)^{2}+\beta\left(P_{(i, t)}-P_{(i, t-1)}\right)^{2}
$$

In this equation, the firm pays a penalty for deviation from its optimal value $(\alpha)$ and it also pays an adjustment cost to change from one time-period to the next $(\beta)$, which is consistent with the idea that firms can achieve high performance when they follow the superior strategy, but there are costs to adjusting to that optimum. By taking the derivative of equation 2 and substituting the optimal value from equation 1, we obtain an equation amenable to estimation:

$$
P_{(i, t)}=\mu\left(\mathrm{S}_{(i, t)}-\mathrm{S}_{(i, t)}\right)+\rho P_{(i, t-1)}
$$


This model specification is used in economics because it controls for substantial variance that might otherwise be attributed to alternative explanations (Greene, 2003). We included the firm's previous year performance $-P(\mathrm{t}-1)$ - on the right side of the equation above, because it removes variance caused by factors that are not highly time-variant (on a year-to-year basis) such as organizational resources and inertia (e.g., routines that create entrenchment in certain paths) and economic or institutional factors such as regulatory and legal adjustment costs. We also included dummy variables for each year as controls (Certo and Semadeni, 2006). We estimate this model with feasible generalized least squares, which allows us to specify temporal autocorrelation as well as heteroskedasticity in the residuals. In this model, we control for lagged values of ROE, revenues, number of employees, the initial (1980) value of ROE, and time indicators. Table 3 provides descriptive statistics and correlations for this model.

Table 4 provides hypothesis testing for $\mathrm{H} 4 \mathrm{a}-\mathrm{H} 4 \mathrm{c}$. All equations given above are statistically significant. In all models, about $65 \%$ of this year's performance is explained by last year's performance. The first equation estimates the premium for following the hypothesized sequencing of strategic responses after deregulation (Hypothesis 4a) and is reported in column 1 of Table 4. The variable of interest is Optimum, coded as one if a firm is following the hypothesized strategic response path within the same time-period the first mover does (who stays engaged in each step for several years), and zero otherwise, estimating the coefficient mu in equation 3. The results provide support for Hypothesis 4a. Following the optimum strategy was worth approximately $1.1 \%$ premium; with a mean ROE over the period of $9 \%$, this premium represents a $12 \%$ gain.

Further, we find that the longer a firm waits to follow the hypothesized step on the superior path, the lower its performance. As shown in the second equation, reported in column 2, we calculate the log of duration of time (in years) off the superior path, termed deviation. We find an increasing penalty; the coefficient on Deviation is negative and significant, providing support for Hypothesis $4 \mathrm{~b}$. Finally, in the third equation, reported in column 3, deviations over time accumulate to the detriment of the firm's ROE; the coefficient on Cumulative Deviations is negative and significant, corroborating Hypothesis 4c. Thus, 
we find that the following strategic response path and making strategic responses in a speedy fashion after the first mover matter to firm performance (H4a-4c).

Insert Table 3 and Table 4 about here

\section{Post-Hoc Analysis of Potential Antecedents of Survival}

Our focus is the consequences of sequencing and timing of competitive moves following industry disruption. However, we seek to offer some insight into why some firms adopted the superior path and others did not. Key drivers of firms' strategic responses may be their initial conditions and capabilities, and we explore these here as a post-hoc analysis where we utilize an ordered probit model. To understand why some firms could follow the proposed sequence and others did not, we model the ability of the firms to do so as a function of their initial resources and capabilities (in 1980) and use the taxonomy suggested by Christensen (2012), which involves resources, processes, and culture as key antecedents of a firm's ability to response to an industry disruption. Resources represent the asset base of the firm, and are captured by the log of assets. Processes collectively reflect a capability, in this case, the capability to run the railroad. In the regulated era, the most important capability of the railroad was to run efficiently; hence, we used a measure of efficiency common to the industry, expenses per freight car mile. As a proxy for culture, we use entrepreneurial orientation, because it is a crucial element of dynamic managerial capability that shapes strategic renewal.

In constructing our entrepreneurial orientation indicator, we relied on entrepreneurship theory, which suggests that managers can have a certain predisposition to act in an entrepreneurial fashion, to identify and exploit opportunities in their industries faster, better, or more extensively than others (Lumpkin and Dess, 1996; Miller, 1983). Managers exhibiting an entrepreneurial orientation are more likely to revitalize, renew, or grow firms. Therefore, entrepreneurial orientation reflects attributes of innovativeness, risk-taking, and proactiveness. 
Following Miller and Le Breton-Miller (2011), we use archival data to measure the firm's entrepreneurial orientation and construct an index that captures the proactivity and risk-taking components of entrepreneurial orientation. We calculate this measure by multiplying the firm's capital expenditures and cost of capital, which is then divided by the operating revenue of the railroad. The capital expenditure level of a railroad reflects the proactivity of its management, because it represents the amount of capital that is put at risk in the face of an uncertain future. This measure also considers risktaking, as two firms that invest the same amount of capital may be undertaking different levels of risk if one is subject to a much higher cost of capital. Dividing by operating revenue standardizes the scale of investments relative to firm size, as large firms are likely to invest more.

After missing data on newly added variables, we were able to run this analysis on 34 firms. Table 5 provides descriptive statistics and correlations for the post-hoc analysis $(n=34)$. As shown in Table 6, a positive coefficient suggests a higher likelihood of following the optimal strategic response path as defined in our theory. The results show that, of the three likely drivers of strategic responsiveness after an industry disruption, two of them are statistically significant. Capability to run the railroad efficiently (captured by expenses per freight car mile) increases the likelihood of a firm to follow the optimal response path. The statistical significance of this variable disappears when we control for the number of employees; however, this result is expected as the employees are part of the expense of running the railroad. We also show that entrepreneurial orientation (as the culture variable) increases the likelihood of a firm to follow the optimal response path, and this variable is robust in both models. This ordered probit model indicates that the two key drivers of firm's responsiveness to deregulation (through taking steps on the optimal response path) are its entrepreneurial orientation and its capability to run the railroad efficiently. The proxy for resources, the asset base of the firm, did not predict the firm's responsiveness.

Insert Table 5 and Table 6 about here 


\section{DISCUSSION}

In this study, we examined the aftermath of the 1980 Staggers Rail Act -- a major deregulation in the U.S. railroad industry -- that marked the end of a regulatory regime that lasted about a century. During this time-period, "through combinations with other systems, railroads formed the most efficient network yet realized for delivering freight to existing rail markets throughout the United States. Unifications with motor and water carriers generated comprehensive transportation networks for delivering freight door-todoor domestically and around the world" (Burns, 1998:4). We find that, in the newly-defined competitive environment, both the sequencing and the timing of response strategies matter to the survival of incumbent firms. Sequencing of response strategies is critical because firms step by step eliminated the deep inefficiencies inherited from the regulation era, re-calibrated their core competencies, and then leveraged their strengths to enter new markets, first through diversification into the broader transportation industry and then diversification into international markets. Strategic moves made in one time-period provided a foundation for the following step in successive time-periods. Early movers taking the optimal strategic response path could create market positions ahead of others and more effectively utilize acquisitions as a strategic tool to quickly transform their competencies and market positions as industry standards on service quality increased along with the emergence of competitive pricing.

In the railroad industry, transitioning from the status quo strategy of market penetration via internal growth to market development via acquisitions enabled firms to build an early cost advantage. Railroads that pursued market development through acquisitions captured bigger gains in operational efficiency and increased their pool of resources, becoming more competitive on pricing and service quality. Acquisitions also enabled firms to expand their railroad network geographically faster and offer broader transportation coverage for their customers who could now ship freight longer distances without delays and costly handling. Incumbents that failed to pursue market development via acquisitions fell behind in their recalibration of core competencies and development of new advantages. The longer these firms waited to switch to the optimal response strategy, the wider the competency gap became, and they 
were left with inferior collaboration choices as the available pool of firms kept shrinking (McNamara et al., 2008). Burns states that: "railroad leaders learned quickly... [that] corporate mergers could integrate the operations of different railroads under one managerial structure, provide market penetration, and eliminate internecine competition. Indirect benefits of combinations included a better utilization of rolling stock, a decline in fuel expenditures, and a reduction in employment costs per unit of output" (1998: 174).

The next two steps of firms' strategic renewal involved expanding firms' product-service scope and geographical scope internationally. Diversification into alternative modes of transportation enabled these firms to develop an inter-modal capability (a complex transportation network capability combining rail with trucking, barges, and ocean freight) that allows door-to-door shipping. Entry into related modes of transportation enabled railroad firms to develop competencies in these domains and integrate them with their railroad operations. Being among the first in this diversification move enabled firms to develop experience-based advantages and choose from the most desirable collaboration partners. Our analysis shows that, after developing an inter-modal capability, railroad firms were better prepared for international expansion. This move enabled firms to follow their clients into new terrains. One-stop shipping was preferred by customers who can work with one shipper for a variety of needs and reduce search and transaction costs. Developing strong transportation capabilities and managerial talent (via related diversification) was a precursor to tackling challenges of operating in foreign markets with different institutional environments. Firms that could not satisfy the complex multi-modal transportation and internationalization needs of the clients were eventually locked out of the industry. These firms increasingly fell behind in customer responsiveness (Priem et al., 2012; Shah and Tripsas, 2007). ${ }^{7}$

\footnotetext{
${ }^{7}$ Historical accounts of 1980 U.S. railroad deregulation are consistent with our findings. Burns (1998: 174175) noted: "Rail carriers took quick advantage of this new opportunity. Large rail systems grew even larger in a unification mania that reduced the number of Class I systems from 73 in 1970 to ten by 1997. Among the largest combinations was the BN SF union in 1994, creating a system spanning more than 30,000 miles and generating more than $\$ 8 \mathrm{~b}$ annually.... [R]ailroads expanded intermodally with equal enthusiasm. By the mid1990s, nearly all of the Class I railroads owned or were affiliated with motor and water carriers. It was not uncommon to see rail systems constructing high tech intermodal truck, barge, and port facilities to maximize intermodal operating efficiency... Expansion into intermodal markets provided railroads an important niche in the modern transportation system. No longer were railroads in danger of financial collapse. As members of
} 
The findings of our study underscore that while it is essential to make coherent changes to a firm's corporate strategy and competencies in a newly-defined environment, this renewal needs to be implemented with a well-orchestrated process. Sequencing of strategic responses requires a delicate balance in capturing the efficiencies in new competency and market development and experimenting with novel strategies to expand firms' portfolio of business offerings (March, 1991; Nelson and Winter, 1982; Wernerfelt, 1984). Too early experimentation without a strong foundation of competencies and slack would have caused firms to spiral out of control. Too little experimentation and latching onto familiar strategies would diminish firms' ability to compete in a redefined environment (Amburgey and Miner, 1992). Therefore, the simultaneous pursuit of carefully sequenced competency and market development and customer responsiveness (i.e., leading or matching the pace of the rivals' competency development and responding to increasing customer demands) was imperative for effective strategic renewal.

After observing the performance rewards of a specific sequencing of capability development, late followers may seek to use an acquisition strategy. However, what is left may not offer the right strategic fit. Thus, the limited availability of complementary industry assets (e.g., collaborative arrangements) can be a binding constraint to strategic renewal in a competitive time frame. In time-periods of rapid restructuring in the industry, firms may have a window of opportunity for self-restructuring and renewal. Pioneer firms that quickly build a platform of complementary products can be highly differentiated in the eyes of the customers (Chandler, 1990). This differentiation can result in customer loyalty and long-term contracts, which can lock out new entrants and late followers (Shah and Tripsas, 2007).

Lessons learned here can provide insights for deregulation scenarios and some cases of disruptive events that may require firms to significantly modify their capabilities. We do not claim that firms will follow the very specific optimal sequencing of strategic responses shown in this study. Instead, we

intermodal networks, rail carriers became an integral element in the door to door movement of freight in the US and in the shipment of cargo to and from markets around the world. Railroads became part of global transportation enterprises, and, in doing so, they developed into prosperous corporations." 
maintain that the principle of sequencing abstracted from this study may be applicable to other scenarios. This involves creating a unique and contingent sequencing of strategic renewal responses that are appropriate for the competitive environment at hand. The insight we offer here is for incumbent firms with existing asset stocks and commitments, where the choice of strategic responses should allow for synergistic sequencing of competency and market development. Incumbent firms must find ways to economize-i.e., re-calibrate, leverage, and build on some of their core competencies while consecutively adding new competencies and learning in new markets. These firms need to find ways to create and capture resources and slack to be deployed for new entrepreneurial initiatives and growth directions.

As our post-hoc analysis indicates, not all incumbents can make a transition in the face of industry disruption. Firms entering the newly competitive landscape with strong asset stocks have a better likelihood of survival, because transformation requires resources to buffer mistakes and to engage in a speedy resource acquisition process. However, a strong resource base by itself is also insufficient. Firms still differ in the strategic response paths they pursue (and how they time their responses) even after controlling for the resources and operational efficiency. Our analysis indicates that making desirable strategic responses also involves entrepreneurial orientation and calculated risk taking. Strategic responses of managers require entrepreneurial vision about how events may unfold, the likely speed of change (as driven by changing customer demands and competitor readiness to respond), and the tacit knowledge of the firm's unique strengths and vulnerabilities — all of which need to be used together to craft the proper sequencing and timing of competitive responses. The fact that firms differed from each other in entrepreneurial orientation even in this industry, where managerial discretion was suppressed for about a century, highlights the importance of dynamic managerial capabilities in driving the orchestration efforts to revitalize and reconfigure firm's capabilities in the face of change (Adner and Helfat, 2003; Kor and Mesko, 2013).

We note some boundary conditions for our theory and findings. First, our study has focused only on incumbent firm response strategies; thus, the renewal path identified here may not be appropriate for 
new entrants. In this industry, new entry was deterred by excess capacityand modest returns under regulatory regime and early post-deregulation period, but in other deregulated markets, new competition may enter the industry and follow a different strategic trajectory. Second, even though some firms made acquisitions before deregulation, the intensity and diversity of acquisitions (same industry, related industry, or international acquisitions) took a different character in the post-deregulation period. We couldn't control for acquisitions prior to the 1980 deregulation due to lack of systematic data. Third, our theory is characterized by significant deregulation that brought a response-urgency as several restrictions were lifted at once, and early response strategies via acquisitions created a rapidly-closing strategic factor market. In the absence of a response-urgency, firms will have a broader set of strategic response options, which they can implement in a gradual fashion (e.g., related diversification through internal growth). In the context of our study, the presence of time lags in internal capability development (Pacheco-deAlmeida et al., 2008), the limited availability of complementary industry assets (e.g., target firms with desirable capabilities) (Dierickx and Cool, 1989), and lead rivals' speedy and efficient responses made acquisitions a superior mode of developing new competencies in a particular order. Fourth, while we emphasize timing of strategic responses, first-mover advantages depend on the state of customer expectations (Schilling, 2002). In the early stages of new market development (or disruption) when customer expectations are not fully shaped, being among the industry pioneers is less critical. It is the later stages of market development, where customer expectations are more certain that there is greater likelihood of persistence in a dominant model or strategy. U.S. railroad firms faced high customer expectations of competitive pricing due to the competitive trucking industry. Deregulation and speedy cost-cutting efforts of some railroad firms escalated these pressures. First-mover advantages were also present in the race to build large physical railroad networks and an intermodal capability. Firms that offered superior services such as extensive coverage and enhanced service quality created a differentiation advantage. Yet, such effects may not be prevalent in other industries. Fifth, firm-level and industry conditions not only drive the optimality of response strategies, but also may allow for multiple 
optimal paths. For example, based on circumstances, some firms may significantly benefit from expanding services internationally before they pursue related diversification. Due to market or firm-level conditions, it may be better for some firms to enter markets with different modes. The optimal response path(s) will be shaped by nature of the environmental shift (e.g., urgency and magnitude of change) and the capabilities and choices of the players in these markets. Sixth, we acknowledge that the railroad industry is a unique industry by being highly capital-intensive and geographically bound, and it is subject to significant historical differences in how it started and evolved over time in different countries. For example, European railroads have been nationalized since the 1920s. Many have been privatized since then although both state and private railroads operate in some countries (sometimes with different infrastructures). In some European markets, infrastructure ownership is separated from operation, which is quite different than the U.S. freight railroad system. Given significant differences across geographical markets in ownership, governance, and competitive conditions that affect railroads, we do not make generalizability claims about how our findings may apply to railroads in other countries.

In conclusion, our study contributes to the literatures on strategic renewal and competitive strategy in the following ways. First, our unique focus on the sequencing of strategic responses enables us to demonstrate that it is not the single strategic choice or response per se, but the sequencing of consecutive strategic responses that drive an incumbent firm's survival in the face a significant shift in the industry. Second, we unpack how firms modify and renew their resource and competency base following the industry disruption of deregulation. Successful renewal efforts involve a balance in responding to demand-side pressures and pursuing an internally efficient new capability acquisition and learning path. Third, we demonstrate that, in the aftermath of deregulation, acquisitions can constitute a powerful competitive strategy - separating survivors from non-survivors - when they are sequenced and timed to allow both market responsiveness and resource-based efficiencies. A strategically coherent path of acquisitions was the key to securing new resources and market positions in a speedy manner while also 
capturing efficiencies. Thus, realizing the benefits of acquisitions may hinge on sequencing them as strategic moves as well as their proper timing vis-a-vis other players.

Finally, our study highlights the distinction between taking a sequencing approach versus a discrete approach to examining the strategic responses to industry disruption. In our sequencing approach, an optimal sequence of multiple strategic responses was identified with inter-linkages between the steps in relation to the firm's evolving corporate strategy and competitive environment. In the alternative discrete approach, one would have looked at whether firms diversified, made acquisitions, or made (any) strategic change in a given year (or time-period). Yet, these discrete choices are not connected to each other in a logical pattern or time sequence. The optimal response strategy we theorized about involves a series of strategic responses through which incumbent firms grew and transformed their corporate and competitive strategies. Each step on this optimal growth path prepared them for the next step.

In this sense, our research setting captures a scenario where firms that have been constrained to develop a limited set of resources and capabilities in a specific geography are suddenly unleashed to find a new equilibrium. We find the striking fact that a single pathway to survival and profitability emerged, and the major difference is how far each firm went along that path. Had we taken a discrete approach to our study, we would not have discovered the optimal strategic path that existed in the aftermath of a major deregulation. Thus, we welcome future research that further advances our understanding of strategic renewal following industry disruption, and encourage new research about the sequencing and timing of strategic responses as an industry disruption unfolds. 


\section{REFERENCES}

Adams R, Almeida H, and Ferreira, D (2009) Understanding the relationship between founder-CEOs and firm performance. Journal of Empirical Finance 16: 136-150.

Adner R and Helfat CE (2003) Corporate effects and dynamic managerial capabilities. Strategic Management Journal 24: 1011-1025.

Aguilera RV and Jackson G (2003) The cross-national diversity of corporate governance: Dimensions and determinants. Academy of Management Review 28: 447-465.

Alvarez SA and Busenitz LW (2001) The entrepreneurship of resource-based theory. Journal of Management, 27: 755-775.

Amburgey TL and Miner AS (1992) Strategic momentum: The effects of repetitive, positional, and contextual momentum on merger activity. Strategic Management Journal 13: 335-348.

Ansoff HI (1965) Corporate Strategy: An Analytic Approach to Business Policy for Growth and Expansion. New York: McGraw-Hill.

Argyres N (1996) Capabilities, technological diversification and divisionalization. Strategic Management Journal 17: 395-410.

Augier M and Teece DJ (2009) Dynamic capabilities and the role of managers in business strategy and economic performance. Organization Science 20: 410-421.

Barr F, Stimpert J and Huff A. 1992. Cognitive change, strategic action and organizational renewal. Strategic Management Journal 13 (Summer): 15-36.

Berman J (2010) STB reauthorization bill is formally introduced. Logistics Management 49: 13-14.

Brealey R, Myers S and Marcus A (2009) Corporate Finance New York: McGraw-Hill Irwin.

Burgelman RA (1983) A process model of internal corporate venturing in the diversified major firm. Administrative Science Quarterly 28: 223-244.

Burns JB (1998) Railroad Mergers and the Language of Unification. Westport, Conn: Quorum Books.

Capron L, Dussauge P and Mitchell W (1998) Resource redeployment following horizontal acquisitions in Europe and North America: 1988-1992. Strategic Management Journal 19: 631-661.

Capron L and Mitchell W (1998) Bilateral resource redeployment and capabilities improvement following horizontal acquisition. Industrial and Corporate Change 7: 453-484.

Carow K, Heron R and Saxton T (2004) Do early birds get the returns? An empirical investigation of early-mover advantages in acquisitions. Strategic Management Journal 25: 563-585.

Caves RE and Porter ME (1977) From entry barriers to mobility barriers: Conjectural decisions and contrived deterrence to new competition. Quarterly Journal of Economics 91: 241-262. 
Certo TS and Semadeni M (2006) Strategy research and panel data: Evidence and implications. Journal of Management 32: 449-462.

Chandler AD (1990) Scale and Scope: The Dynamics of Industrial Capitalism. Cambridge, MA: Harvard University Press.

Chang SJ and Singh H (1999) The impact of modes of entry and resource fit on modes of exit by multibusiness firms. Strategic Management Journal 20: 1019-1035.

Chatterjee S (1990). Excess resources, utilization costs, and mode of entry. Academy of Management Journal 33: 780-800.

Chen M-J (1996) Competitor analysis and interfirm rivalry: Toward a theoretical integration. Academy of Management Review 21: 100-134.

Chen P-L, Williams C and Agarwal R (2012). Growing pains: Pre-entry experience and the challenge of transition to incumbency. Strategic Management Journal 33: 252-276.

Christensen CM, Allworth J and Dillon K (2012) How Will You Measure Your Life? New York: Harper Collins.

Cooksey RW (2007) Illustrating Statistical Procedures. Prahran, Victoria, Australia: Tilde University Press.

Dierickx I and Cool K (1989) Asset stock accumulation and sustainability of competitive advantage. Management Science 35: 1504-1529.

Eisenhardt KM and Martin J (2000) Dynamic capabilities: What are they? Strategic Management Journal 21(Summer): 1105-1121.

Garrette B, Castaner X and Dussauge P (2009) Horizontal alliances as an alternative to autonomous production: Product expansion mode choice in the worldwide aircraft industry. Strategic Management Journal 30: 885-894.

Ghemawat P (1991) Commitment. New York: The Free Press.

Greene WH (2003) Econometric Analysis (5th ed.). Upper Saddle River, NJ: Prentice-Hall.

Guthrie JP, Grimm CM and Smith KG (1991) Environmental change and management staffing: An empirical study. Journal of Management 17: 735-748.

Haleblian J and Finkelstein S (1999) The influence of organizational acquisition experience. Administrative Science Quarterly 44, 29-56.

Haleblian J, McNamara G, Kolev K and Dykes B (2012) Exploring firm characteristics that differentiate leaders from followers in industry merger waves: A competitive dynamics approach. Strategic Management Journal 33: 1037-1052. 
Hambrick D, Cho T, Chen M-J (1996) The influence of top management team heterogeneity on firms' competitive moves. Administrative Science Quarterly 41(4): 659-684.

Heckman J (1979) Sample selection bias as a specification error. Econometrica 47: 153-161.

Helfat CE, Finkelstein S, Mitchell W, Peteraf M, Singh H, Teece D and Winter SG (2009) Dynamic Capabilities: Understanding Strategic Change in Organizations. New York: John Wiley \& Sons.

Helfat C and Peteraf M (2003) The dynamic RBV: Capability lifecycles. Strategic Management Journal 24: 999-1010.

Hitt MA, Bierman L, Uhlenbruck K and Shimizu K (2006a) The importance of resources in the internationalization of professional service firms: The good, the bad, and the ugly. Academy of Management Journal 49: 1137-1157.

Hitt MA, Tihanyi L, Miller T and Connelly B. (2006b) International diversification: Antecedents, outcomes, and moderators. Journal of Management 32: 831-867.

Jayaratne J and Strahan PE (1998) Entry restrictions, industry evolution, and dynamic efficiency: Evidence from commercial banking. Journal of Law and Economics 41: 239-274.

Johanson J and Vahlne JE (1977) The internationalization process of the firm -- a model of knowledge development and increasing foreign market commitments. Journal of International Business Studies 8: 23-32.

Johanson J and Vahlne JE (2009) The Uppsala internationalization process model revisited: From liability of foreignness to liability of outsidership. Journal of International Business Studies, 40: 1411-1431.

Kaul A (2012) Technology and corporate scope: Firm and rival innovation as antecedents of corporate transactions. Strategic Management Journal 33: 347-367.

Kim B and Prescott JE (2005) Deregulatory forms, variations in the speed of governance adaptation, and firm performance. Academy of Management Review 30: 414-425.

Kim J-Y and Finkelstein S (2009) The effects of strategic and market complementarity on acquisition performance: Evidence from the U.S. commercial banking industry, 1989-2001. Strategic Management Journal 30: 617-646.

King DR, Dalton, DR, Daily CM and Covin JG (2004) Meta-analyses of post-acquisition performance: Indications of unidentified moderators. Strategic Management Journal 25: 187-200.

Klarner P and Raisch S (2013) Move to the beat - Rhythms of change and firm performance. Academy of Management Journal 56: 160-184.

Kor YY and Leblebici H (2005) How do interdependencies among human-capital deployment, development, and diversification strategies affect firms' financial performance? Strategic Management Journal 26: 967-985. 
Kor YY and Mahoney JT (2000) Penrose's resource-based approach: the process and product of research creativity. Journal of Management Studies 37: 109-139.

Kor YY and Mahoney JT (2005) How dynamics, management, and governance of resource deployments influence firm-level performance. Strategic Management Journal 26: 489-496.

Kor YY, Mahoney JT and Michael SC (2007) Resources, capabilities, and entrepreneurial perceptions. Journal of Management Studies 44: 1185-1210.

Kor YY and Mesko A (2013) Dynamic managerial capabilities: Configuration and orchestration of top executives' capabilities and the firm's dominant logic. Strategic Management Journal 34: 233-244.

Kostova T, Roth K and Dacin MT (2008) Institutional theory in the study of multinational corporations: A critique and new directions. Academy of Management Review 33: 994-1006.

Laamanen $\mathrm{T}$ and Keil $\mathrm{T}$ (2008) Performance of serial acquirers: toward an acquisition program perspective. Strategic Management Journal 29: 663-672.

Lafontaine F and Shaw KL (1999) The dynamics of franchise contracting: Evidence from panel data. Journal of Political Economy 107: 1041-1080.

Langley A, Smallman C, Tsoukas H and Van de Ven A (2013) Process studies of change in organization and management: Unveiling temporality, activity, and flow. Academy of Management Journal 56: 1-13.

Lee GK and Lieberman MB (2010) Acquisition vs. internal development as modes of market entry. Strategic Management Journal 31: 140-158.

Lieberman MB and Montgomery DB (1988) First-mover advantages. Strategic Management Journal 9(Summer): 41-58.

Lumpkin GT and Dess GG (1996) Clarifying the entrepreneurial orientation construct and linking it to performance. Academy of Management Review 21: 135-172.

Mahon JF and Murray EA (1981) Strategic planning for regulated companies. Strategic Management Journal 2: 251-262.

Mahoney JT and McGahan AM (2007) The field of strategic management within the evolving science of strategic organization. Strategic Organization 5: 79-99.

Mahoney JT and Pandian JR (1992) The resource-based view within the conversation of strategic management. Strategic Management Journal 13: 363-380.

March JG (1991) Exploration and exploitation in organizational learning. Organization Science 2: 71-87.

Markides CC and Ittner CD (1994) Shareholder benefits from corporate international diversification: Evidence from US international acquisitions. Journal of International Business Studies 25: 343-366.

McGrath RG (1999) Falling forward: Real options reasoning and entrepreneurial failure. Academy of Management Review 24: 13-30. 
McNamara GM, Haleblein J and Dykes BJ (2008) The performance implications of participation in an acquisition wave: Early mover advantages, bandwagon effects, and the moderating influence of industry characteristics and acquirer tactics. Academy of Management Journal 51: 113-130.

Miller D (1983) The correlates of entrepreneurship in three types of firms. Management Science 29: 770791.

Miller D and Friesen P (1984) A longitudinal study of the corporate life cycle. Management Science 30: 1161-1183.

Miller D and Le Breton-Miller I (2011) Governance, social identity, and entrepreneurial orientation in closely held public companies. Entrepreneurship: Theory and Practice 35: 1051-1076.

Mintzberg $\mathrm{H}$ and Waters JA (1982) Tracking strategy in an entrepreneurial firm. Academy of Management Journal 25: 465-499.

Nelson RR and Winter SG (1982) An Evolutionary Theory of Economic Change. Cambridge, MA: Belknap Press of Harvard University Press.

Pacheco-de-Almeida G, Henderson JE and Cool KD (2008) Resolving the commitment versus flexibility tradeoff: The role of resource accumulation lags. Academy of Management Journal 51: 517-536.

Pacheco-de-Almeida G and Zemsky P (2007) The timing of resource development and sustainable competitive advantage. Management Science 53: 651-666.

Pelz DC (1985) Innovation complexity and the sequence of innovating stages. Science Communication 6: 261-291.

Penrose ET (1959) The Theory of the Growth of the Firm. New York: John Wiley \& Sons.

Penrose ET (1960) The growth of the firm. A case study: The Hercules Powder Company. Business History Review 34: 1-23.

Peteraf M and Reed R (2007) Managerial discretion and internal alignment under regulatory constraints and change. Strategic Management Journal 28: 1089-1112.

Phene A, Tallman S and Almeida P (2012) When do acquisitions facilitate technological exploration and exploitation? Journal of Management 38: 753-783.

Phillips A (1991) Changing markets and institutional inertia: A review of US telecommunications policy. Telecommunications Policy 15: 49-61.

Poppo L and Zenger T 1998. Testing alternative theories of the firm: Transaction cost, knowledge-based, and measurement explanations for make-or-buy decisions in information services. Strategic Management Journal 23: 707-725.

Priem RL 2007. A consumer perspective on value creation. Academy of Management Review 32: 219235. 
Priem RL, Li S and Carr JC (2012). Insights and new directions from demand-side approaches to technology innovation, entrepreneurship, and strategic management research. Journal of Management 38: $346-374$.

Reger R, Duhaime IM and Stimpert JL (1992) Deregulation, strategic choice, risk and financial performance. Strategic Management Journal 13: 189-204.

Richard PJ, Devinney TM, Yip GS and Johnson G (2007) Measuring organizational performance: Towards methodological best practices. Journal of Management 35: 718-804.

Robinson WT (1988) Marketing mix reactions to entry. Marketing Science 7: 368-385.

Robinson WT and Fornell C (1985) Sources of market pioneer advantages in consumer goods industries. Journal of Marketing Research 22: 305-317.

Rumelt RP (1984) Toward a strategic theory of the firm. In: R Lamb (Ed) Competitive Strategic Management. Englewood Cliffs, NJ: Prentice-Hall, pp. 556-570.

Rumelt RP, Schendel D and Teece DJ (1991) Strategic management and economics. Strategic Management Journal 12: 5-29.

Schilling MA (2002) Technology success and failure in winner-take-all markets: The impact of learning orientation, timing, and network externalities. Academy of Management Journal 45: 387-398.

Schmidt J and Keil T (2013) What makes a resource valuable? Identifying the drivers of firmidiosyncratic resource value. Academy of Management Review 38: 206-228.

Shah SK and Tripsas M (2007) The accidental entrepreneur: The emergent and collective process of user entrepreneurship. Strategic Entrepreneurship Journal 1: 123-140.

Shaver JM (1998) Accounting for endogeneity when assessing strategy performance: Does entry mode choice affect FDI survival? Management Science 44: 571-585.

Shi WS and Prescott JE (2011) Sequence patterns of firms' acquisition and alliance behaviour and their performance implications. Journal of Management Studies 48: 1044-1070.

Shi WS and Prescott JE (2012) Rhythm and entrainment of acquisition and alliance initiatives and firm performance: A temporal perspective. Organization Studies 33: 1281-1310.

Silverman BS (1999) Technological resources and the direction of corporate diversification: Toward an integration of the resource-based view and transaction cost economics. Management Science 45: 1109-1124.

Silverman B, Nickerson J and Freeman J (1997) Profitability, transactional alignment and generalization mortality in the U.S. trucking industry. Strategic Management Journal 18: 31-52.

Smit H and Moraitis T (2010) Playing at serial acquisitions. California Management Review 53(1): 56-89. 
Smith K and Grimm C (1987) Environmental variation, strategic change and firm performance: A study of railroad deregulation. Strategic Management Journal 8: 363-376.

Spulber DF (1989) Regulation and Markets. Cambridge, MA: MIT Press.

Teece DJ (1982) Towards an economic theory of the multi-product firm. Journal of Economic Behavior and Organization 3: 39-63.

Teece DJ (1986) Profiting from technological innovation: Implications for integration, collaboration, licensing and public policy. Research Policy 15: 285-305.

Thomas LA (1996) Advertising sunk costs and credible spatial preemption. Strategic Management Journal 17: 481-498.

Tripsas M (1997). Unraveling the process of creative destruction: Complementary assets and incumbent survival in the typesetter industry. Strategic Management Journal 18: 119-142.

Urban GL, Carter T, Gaskin S and Mucha Z (1986) Market share rewards to pioneering brands: An empirical analysis and strategic implications. Management Science 32: 645-659.

Van de Ven, AH (2007) Engaged Scholarship: A Guide for Organizational and Social Research. Oxford, UK: Oxford University Press.

Verona G and Ravasi D (2003) Unbundling dynamic capabilities: An exploratory study of continuous product innovation. Industrial and Corporate Change 12: 577-606.

Walker G, Madsen TL and Carini G (2002) How does institutional change affect heterogeneity among firms? Strategic Management Journal 23: 89-104.

Wernerfelt B (1984) A resource-based view of the firm. Strategic Management Journal 5: 171-180.

Wiggins RR and Ruefli TW (2002) Sustained competitive advantage: Temporal dynamics and the incidence and persistence of superior economic performance. Organization Science 13: 81-105.

Winston C, Corsi TM, Grimm CM and Evans CA (1990). The Economic Effects of Surface Freight Deregulation. Washington, DC: The Brookings Institution.

Yip GS (1982) Diversification entry: Internal development versus acquisition. Strategic Management Journal 3: 331-345.

Zahra S and Pearce J (1990) Research evidence on the Miles-Snow typology. Journal of Management 16: 751-768.

Zollo M and Meier D (2008) What is M\&A performance? Academy of Management Perspectives 22: 55-77.

Zollo M and Winter SG (2002) Deliberate learning and the evolution of dynamic capabilities. Organization Science 13: 339-351.

Acknowledgements: We thank Professor Gianmario Verona (co-editor, Strategic Organization) and the three anonymous reviewers of this article for their guidance and helpful comments. The usual disclaimer applies. 


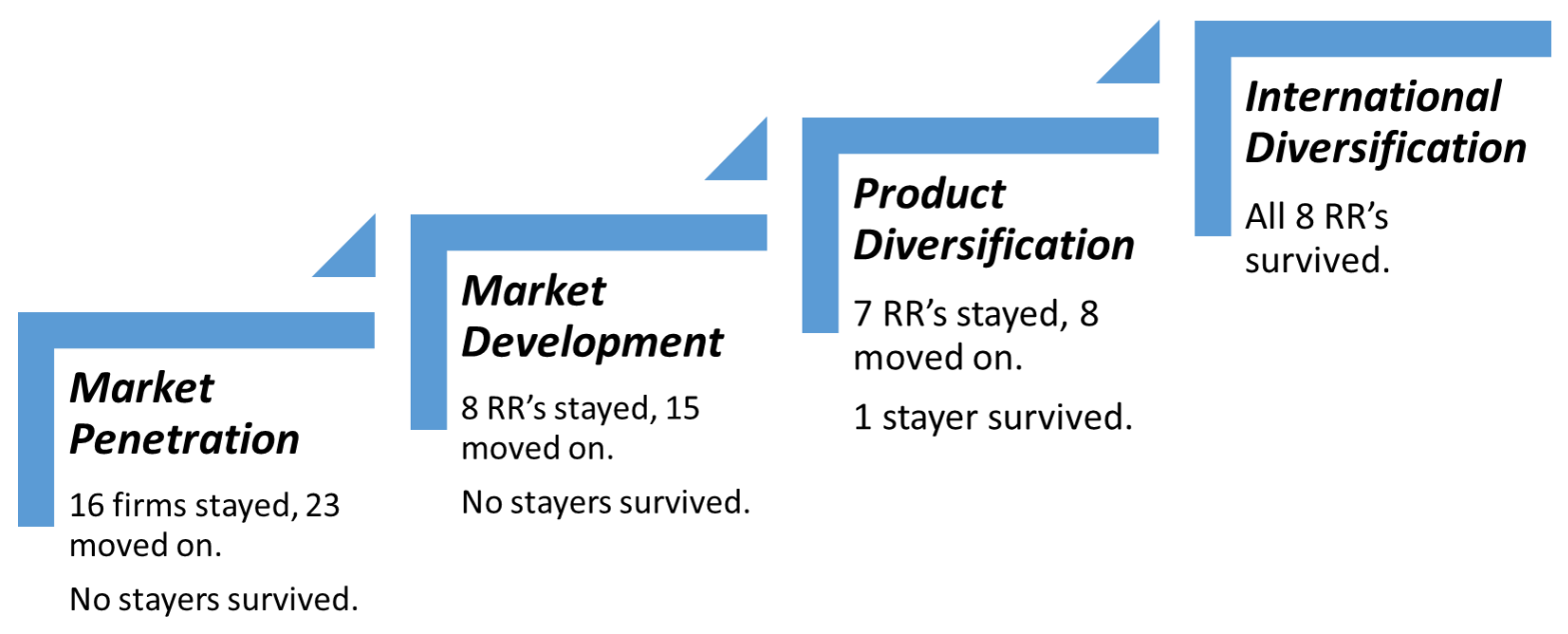

Figure 1. Sequencing of Strategic Responses in the US Railroad Industry (1980-2003) 
Table 1. Coding matrix for the firm's growth strategy.

\begin{tabular}{|l|l|}
\hline Rater Matrix Coding Scheme: & Firm's Growth Strategy \\
\hline Internal development & $\begin{array}{l}\text { Market penetration } \\
\text { (status quo for all firms) }\end{array}$ \\
\hline $\begin{array}{l}\text { Same industry acquisition } \\
\text { (trucking industry) }\end{array}$ & Market development \\
\hline $\begin{array}{l}\text { Domestic strategic alliance } \\
\text { (trucking industry) }\end{array}$ & $\begin{array}{l}\text { Related product } \\
\text { diversification }\end{array}$ \\
\hline $\begin{array}{l}\text { International strategic alliance } \\
\text { (with railroad firms) }\end{array}$ & $\begin{array}{l}\text { Related product } \\
\text { diversification }\end{array}$ \\
\hline $\begin{array}{l}\text { International related acquisition } \\
\text { (with railroad firms) }\end{array}$ & International diversification \\
\hline $\begin{array}{l}\text { Acquired by another firm } \\
\text { Out of business }\end{array}$ & $\begin{array}{l}\text { Failed to exist as an } \\
\text { independent firm }\end{array}$ \\
\hline independent firm \\
\hline
\end{tabular}


Table 2. Survival durations and comparison tests based upon strategic responses (H1-H3) .

\begin{tabular}{|c|c|c|c|}
\hline & Total Sample & & \\
\hline \# of Railroads & 39 & & \\
\hline Mean Survival & 10.2 years & SD Survival & 7.3 years \\
\hline
\end{tabular}

First Step (H1): Hypothesized superior response = Market Development

Alternative response $=$ Status quo Market Penetration

\begin{tabular}{|c|c|c|c|c|}
\hline & $\begin{array}{c}\text { Market } \\
\text { Development }\end{array}$ & $\begin{array}{c}\text { Market } \\
\text { Penetration }\end{array}$ & $\begin{array}{c}\text { Comparison of } \\
\text { Means }\end{array}$ & $\begin{array}{c}\text { Comparison of } \\
\text { Wilcoxon Rank Sums }\end{array}$ \\
\hline \# of Railroads & 23 & 16 & & \\
\hline Mean & 13.74 & 5.06 & $\mathrm{t}=5.28^{* * * *}$ & $\mathrm{z}=3.62^{* * * *}$ \\
\hline
\end{tabular}

Second Step (H2): Hypothesized Superior Response $=$ Product Diversification

Alternative response $=$ Market Development

\begin{tabular}{|c|c|c|c|c|}
\hline & $\begin{array}{c}\text { Product } \\
\text { Diversification }\end{array}$ & $\begin{array}{c}\text { Market } \\
\text { Development }\end{array}$ & $\begin{array}{c}\text { Comparison of } \\
\text { Means }\end{array}$ & $\begin{array}{c}\text { Comparison of } \\
\text { Wilcoxon Rank Sums }\end{array}$ \\
\hline \# of Railroads & 15 & 8 & & \\
\hline Mean & 18.00 & 5.75 & $\mathrm{t}=6.53^{* * *}$ & $\mathrm{z}=3.67^{* * * *}$ \\
\hline
\end{tabular}

\section{Third Step (H3):}

Hypothesized Superior Response = International Diversification

Alternative response $=$ Product Diversification

\begin{tabular}{|c|c|c|c|c|}
\hline & $\begin{array}{c}\text { International } \\
\text { Diversification }\end{array}$ & $\begin{array}{c}\text { Product } \\
\text { Diversification }\end{array}$ & $\begin{array}{c}\text { Comparison of } \\
\text { Means }\end{array}$ & $\begin{array}{c}\text { Comparison of } \\
\text { Wilcoxon Rank Sums }\end{array}$ \\
\hline \# of Railroads & 8 & 7 & & \\
\hline Mean & 22 & 13.43 & $\mathrm{t}=4.63^{* * *}$ & $\mathrm{z}=3.13^{* * *}$ \\
\hline
\end{tabular}

${ }^{\mathrm{a}} \dagger \mathrm{p}<.10 ; * \mathrm{p}<.05 ; * * \mathrm{p}<.01 ; * * \mathrm{p}<.001$ 
Table 3. Descriptive statistics and correlations for ROE model $(\mathrm{H} 4 \mathrm{a}-\mathrm{H} 4 \mathrm{c})^{\mathrm{a}}{ }^{\text {. }}$

\begin{tabular}{|l|l|r|r|r|r|r|r|r|r|r|r|r|}
\hline & Obs & Mean & SD & Min & Max & 1 & 2 & 3 & 4 & 5 \\
\hline 1 & Return on Equity & 346 & 8.96 & 6.74 & -17.14 & 26.99 & 1.00 & & & \\
\hline 2 & Optimum & 346 & 0.25 & 0.43 & 0 & 1 & 0.24 & 1.00 & & \\
\hline 3 & Deviation & 346 & 3.31 & 3.60 & 0 & 16 & -0.12 & -0.47 & 1.00 & \\
\hline 4 & Cumulative Mistakes & 346 & 5.86 & 4.21 & 0 & 17 & 0.18 & 0.11 & 0.49 & 1.00 & \\
\hline 5 & Employees & 346 & 15,760 & 13,784 & 652 & 91318 & 0.07 & -0.06 & 0.13 & 0.12 & 1.00 \\
\hline 6 & Revenue & 346 & $1,488,656$ & $1,760,968$ & 6,983 & $9,201,022$ & 0.07 & 0.06 & 0.02 & 0.10 & 0.38 & 1.00 \\
\hline 7 & Initial ROE & 346 & 6.11 & 5.138 & -16.79 & 25.7 & 0.19 & -0.14 & 0.23 & -0.01 & 0.22 & 0.39 \\
\hline
\end{tabular}

${ }^{\mathrm{a}}$ Correlations over .10 are significant at the $5 \%$ level. 
Table 4. Performance (ROE) effects over timing of growth strategies $(\mathrm{H4a}-4 \mathrm{c})^{\mathrm{a}}$.

\begin{tabular}{|l|c|c|c|}
\hline & $\begin{array}{c}\text { Optimum } \\
\text { Strategy } \\
(1)\end{array}$ & $\begin{array}{c}\text { Deviations from } \\
\text { Optimum Strategy } \\
(2)\end{array}$ & $\begin{array}{c}\text { Cumulative } \\
\text { Deviations from } \\
\text { Optimum Strategy } \\
(3)\end{array}$ \\
\hline Lagged ROE & $0.647^{* * *}$ & $0.642^{* * *}$ & $0.639^{* * *}$ \\
\hline & $(14.93)$ & $(14.82)$ & $(14.14)$ \\
\hline Optimum & $\mathbf{1 . 0 6 7}$ & & \\
\hline & $\mathbf{( 1 . 9 6 )}$ & & \\
\hline Log (Deviations from & & $\mathbf{- 0 . 8 1 4} * *$ & \\
\hline & & $\mathbf{( 2 . 8 0 )}$ & \\
\hline Lptimum) & & & $\mathbf{- 2 . 9 9 6 * * *}$ \\
\hline & & & -0.113 \\
\hline Prior year revenue & 0.038 & -0.071 & $(0.62)$ \\
\hline & $(0.23)$ & $(0.42)$ & $0.723^{* *}$ \\
\hline Prior year employment & 0.181 & 0.294 & $(3.24)$ \\
\hline & $(0.98)$ & $(1.55)$ & 0.02 \\
\hline Initial 1980 ROE & -0.051 & -0.001 & $(0.39)$ \\
\hline & $(0.97)$ & $(0.02)$ & Yes \\
\hline Time Indicators & Yes & Yes & -1.437 \\
\hline Constant & 0.421 & 1.448 & $(0.52)$ \\
\hline & $(0.16)$ & $(0.57)$ & $432.896^{* * *}$ \\
\hline & & & \\
\hline Chi-squared statistic & $412.247^{* * *}$ & $413.303^{* * *}$ & \\
\hline & & & \\
\hline
\end{tabular}

${ }^{a} \mathrm{~N}=354$. The ROE is calculated as a percentage. The $\mathrm{z}$-statistic is underneath the coefficient estimate. The coefficient tests are two-tailed.

$\dagger \mathrm{p}<.10 ; * \mathrm{p}<.05 ; * * \mathrm{p}<.01 ; * * * \mathrm{p}<.001$ 
Table 5. Descriptive statistics and correlations for ordered probit model of antecedents a

\begin{tabular}{|l|l|r|r|r|r|r|r|r|r|r|r|r|r|r|}
\hline & Obs & Mean & SD & Min & Max & 1 & 2 & 3 & 4 & 5 \\
\hline 1 & Steps & 34 & 1.35 & 1.61 & 0 & 4 & 1.00 & & \\
\hline 2 & Ent. Orientation & 34 & 1.12 & 0.82 & 0.092 & 3.128 & 0.29 & 1.00 & & \\
\hline 3 & Assets & 34 & $1,192,307$ & $1,267,423$ & 97,243 & $4,091,867$ & 0.26 & 0.01 & 1.00 & \\
\hline 4 & Operating Efficiency & 34 & 2.69 & 6.16 & 0.2 & 33 & 0.22 & -0.09 & 0.02 & 1.00 & \\
\hline 5 & \# of Employees & 34 & 15,309 & 12,118 & 776 & 42,659 & -0.29 & 0.11 & -0.01 & -0.19 & 1.00 \\
\hline 6 & Southern District & 34 & 0.18 & 0.39 & 0 & 1 & -0.15 & 0.10 & 0.10 & 0.52 & -0.22 & 1.00 \\
\hline 7 & Western District & 34 & 0.47 & 0.51 & 0 & 1 & 0.38 & 0.08 & 0.06 & -0.18 & 0.25 & -0.44 \\
\hline
\end{tabular}

${ }^{\mathrm{a}}$ Correlations above .33 significant at the $5 \%$ level. 
Table 6. Post-hoc analysis: An ordered probit model of drivers of strategic responses ${ }^{\mathrm{a}}$.

\begin{tabular}{|l|c|c|}
\hline Variables & Model 1 & Model 2 \\
\hline & & \\
Entrepreneurial Orientation & $0.523^{*}$ & $0.836^{* *}$ \\
& $(2.02)$ & $(2.87)$ \\
Firm assets $^{+}$ & 0.235 & 0.323 \\
& $(1.44)$ & $(1.82)$ \\
Expenses per freight car mile & $0.089^{*}$ & 0.084 \\
& $(2.02)$ & $(1.70)$ \\
Employees & & $-0.659^{* *}$ \\
& & $(3.24)$ \\
Regional indicators & & Yes \\
& & \\
\hline & & $26.286^{* * *}$ \\
Chi-squared statistic & $14.984^{*}$ & 6 \\
Degrees of freedom & 5 & 0.305 \\
Pseudo-R-squared & 0.174 & \\
\hline
\end{tabular}

a The ordered probit measures the probability of moving from status quo strategy (market penetration) to step 3 (international diversification) following the optimal sequencing proposed in the study.

$\mathrm{p}<.10 ; * \mathrm{p}<.05 ; * * \mathrm{p}<.01 ; * * * \mathrm{p}<.001$

+ indicates variable was log-transformed. 


\section{Appendix. Estimating the effect of strategic response on survival with endogeneity correction.}

In Table 2, we offered a univariate test of the relative success (as measured by survival) of following the strategies in the sequence that our theorizing predicts. The more methodologically inclined reader may be prone to question those results, given that there is a possibility of selection bias. Railroads may be unable to choose one of the strategies due to a lack of capabilities or resources. Put another way, the strategy is endogenous, and therefore a correction must be made for possible bias. The classic exposition of this issue is found in Heckman (1979) and developed in management in Shaver (1998).

One prominent solution to the problem of endogeneity is instrumental variables techniques (IV). The problem of endogeneity can be represented by a correlation of the error term with the independent variable of interest (here, strategy chosen). The solution is to use as instruments other variables that are strongly correlated with the strategy but less so with the dependent variable (here, survival). This approach is a robust and well-studied solution to the problem, and it eliminates bias at some cost in estimation efficiency.

Applying this general prescription to our data at hand is challenging but can be done. It presents two problems. First, the endogenous variable, strategy, is dichotomous, thus probit would be the natural estimation technique. But the effectiveness of instrumental variables technique is established primarily in the case of linear estimation. Fortunately, a methodology has been developed by Adams, Almeida, and Ferreira (2009) that addresses this problem, to be presented further below. In a related vein, the performance variable, survival, is not normally distributed, with a long tail.

Second, our data set is small. Exacerbating the problem, the sequence requires a smaller data set for each test if we accept the sequence proceeds as market penetration to market development to product development to international diversification. In other words, the most rigorous test of our hypotheses requires us to compare only railroads that have reached the prior step. For example, to test whether survival differs based on whether firms moved to international diversification; a strict test requires us to consider only firms that reached the step of product development. Only 12 firms reached this stage. To address this challenge, we offer two solutions. First, we use liberal levels of statistical significance (as high as .20 in two-tailed tests). Second, we use multiple estimation methods to test our hypotheses. The general approach is "more is better."

To address the first point, Adams and colleagues (2009) suggest the following method: (1) estimate a probit regression with the instruments (predicting strategic response); (2) take the fitted value from the first regression and include it in a linear regression on the dichotomous dependent variable; (3) use the fitted value from the second regression in the primary equation (predicting survival). We use the predictive variables employed in the post-hoc antecedents-model. Suggesting that resources drive strategy offers a strong theoretical reason and a presumption of efficiency to be demonstrated.

Results are presented separately for each step in the sequence. Results from the first step (predicting who followed the strategy) are contained in Table A1.

As in any instrumental variables or two-stage model, the first stage is relevant primarily for producing a good instrument rather than for hypothesis testing. We will report the first-stage regressions only to demonstrate that we have effective instruments for the choice of strategy (effectively checking for positive and significant $\mathrm{p}$-values). The second stage regressions contain our hypothesis tests. 
Table A1. Instrumental variable regression.

\begin{tabular}{|c|c|c|c|c|c|c|}
\hline & $\begin{array}{l}\text { Probit } \\
\text { Market } \\
\text { Development }\end{array}$ & & $\begin{array}{l}\text { Probit } \\
\text { Product } \\
\text { Development }\end{array}$ & & $\begin{array}{l}\text { Probit } \\
\text { International } \\
\text { Diversification }\end{array}$ & \\
\hline \multirow[t]{2}{*}{ Market Share } & 0.473 & $*$ & 0.134 & & 0.153 & \\
\hline & 2.46 & & 1.21 & & 1.20 & \\
\hline \multirow[t]{2}{*}{ Efficiency } & 0.096 & & 0.054 & & 0.034 & \\
\hline & $\begin{array}{r}1.16 \\
0.673\end{array}$ & + & $\begin{array}{r}1.29 \\
0.641\end{array}$ & + & $\begin{array}{l}1.03 \\
0.76\end{array}$ & + \\
\hline Entrepreneurial Orientation & 1.70 & & 1.96 & & 1.87 & \\
\hline \multirow[t]{2}{*}{ First ROE } & 0.079 & $*$ & 0.006 & & 0.031 & \\
\hline & $\begin{array}{r}1.98 \\
-0.561\end{array}$ & & $\begin{array}{r}0.20 \\
-0.085\end{array}$ & & $\begin{array}{r}0.94 \\
-0.046\end{array}$ & \\
\hline Assets ^ & $\begin{array}{l}-1.38 \\
-1.03\end{array}$ & $*$ & $\begin{array}{r}-0.24 \\
-0.282\end{array}$ & & $\begin{array}{r}-0.11 \\
-0.951\end{array}$ & $*$ \\
\hline \multirow[t]{2}{*}{ Constant } & $\begin{array}{r}-3.24 \\
14.602\end{array}$ & $*$ & $\begin{array}{l}-1.20 \\
1.998\end{array}$ & & $\begin{array}{l}-3.27 \\
6.319\end{array}$ & \\
\hline & 2.29 & & 0.41 & & 1.33 & \\
\hline
\end{tabular}

$\wedge \log$ transformed

$\mathrm{t}$ statistics below coefficient estimate; $+\mathrm{p}<0.10, * \mathrm{p}<0.05, * * \mathrm{p}<0.01, * * * \mathrm{p}<0.001$.

These predictions have 34 observations. In all cases, entrepreneurial orientation has a strong and expected positive sign on shifting strategy. Market share and return on equity also have a strong effect.

Our tests of means in Table 2 can be implemented as a regression with the same interpretation on the instrumented, dichotomous variable (strategic response). Thus, a significant coefficient signals a positive effect on survival of following the strategy. Table A2 below reports the result of five regressions. Note that columns 1, 2, and 4 contain all railroads for which we have data $(n=34)$. These results use only 34 due to data availability for the first-stage estimation (versus the 39 railroads at the first step in Table 2, where mean comparisons are made). Here, Column 2 presumes firms that stayed with market penetration were also free to choose product development (without first passing through market development). This is the equivalent of presuming that there is no order to the stepping stones (or running logit model on each strategy separately). We find that following each strategic response has a strong and significant effect on survival. Columns 1,3 , and 5 treat the strategy as a sequence by requiring the railroad to have executed the previous strategy (similar to Table 2). For example, the test on the effectiveness of the product development strategy presumes that the railroad already adopted the market development strategy. Hence, the sample size is smaller $(n=19$ or $n=12)$. 
Table A2. Regression of survival on strategic response

\begin{tabular}{|c|c|c|c|c|c|c|c|c|c|}
\hline REGRESSION & $\begin{array}{c}1 \\
\text { survival }\end{array}$ & & $\begin{array}{c}2 \\
\text { survival }\end{array}$ & & $\begin{array}{c}3 \\
\text { survival }\end{array}$ & & $\begin{array}{c}4 \\
\text { survival }\end{array}$ & & $\begin{array}{c}5 \\
\text { survival }\end{array}$ \\
\hline $\begin{array}{l}\text { Mkt Dev } \\
\text { (t-stat) }\end{array}$ & $\begin{array}{r}10.44 * * \\
3.15\end{array}$ & Prod Dev & $\begin{array}{r}16.18^{* * * *} \\
3.67\end{array}$ & Prod Dev & $\begin{array}{r}13.99+ \\
2.00\end{array}$ & Int'l Div & $\begin{array}{r}10.43 * * \\
2.76\end{array}$ & Int'l Div & $\begin{array}{r}7.23+ \\
\quad 1.92\end{array}$ \\
\hline Constant & $\begin{array}{r}3.543 \\
1.60\end{array}$ & & $\begin{array}{r}3.794 \\
2.00\end{array}$ & & $\begin{array}{r}6.918 \\
1.91\end{array}$ & & $\begin{array}{r}7.556^{* * * *} \\
5.66\end{array}$ & & $\begin{array}{r}15.11^{* * * *} \\
8.03\end{array}$ \\
\hline $\mathrm{N}$ & 34 & & 34 & & 19 & & 34 & & 12 \\
\hline $\begin{array}{l}\text { Corresponds to } \\
\text { in Table } 2\end{array}$ & $\begin{array}{l}\text { First } \\
\text { Step }\end{array}$ & & & & $\begin{array}{l}\text { Second } \\
\text { Step }\end{array}$ & & & & $\begin{array}{l}\text { Third } \\
\text { Step }\end{array}$ \\
\hline
\end{tabular}

$\mathrm{t}$ statistics below coefficient estimate; $+\mathrm{p}<0.10,{ }^{*} \mathrm{p}<0.05,{ }^{* *} \mathrm{p}<0.01, * * * \mathrm{p}<0.001$.

Some may note that survival is a variable with a non-normal distribution, and hence the traditional assumptions of a normal error term are likely to be violated. To address this point, we offer the Cox hazard model. The Cox model is non-linear, which makes the IVT problematic, but it is also less sensitive to distributional assumptions generally. Below is reported the results with a Cox duration model. Remembering that a negative sign indicates a positive effect on survival, our hypotheses are again corroborated.

Table A3. Regression of survival on strategic response

\begin{tabular}{|c|c|c|c|c|c|c|c|c|c|}
\hline $\mathrm{COX}$ & $\begin{array}{c}1 \\
\text { survival }\end{array}$ & & $\begin{array}{c}2 \\
\text { survival }\end{array}$ & & $\begin{array}{c}3 \\
\text { survival }\end{array}$ & & $\begin{array}{c}4 \\
\text { survival }\end{array}$ & & $\begin{array}{c}5 \\
\text { Survival }\end{array}$ \\
\hline Mkt Dev & $\begin{array}{l}-2.071^{* *} \\
(2.95)\end{array}$ & $\begin{array}{l}\text { Prod } \\
\text { Dev }\end{array}$ & $\begin{array}{l}-2.274 * * \\
(2.62)\end{array}$ & $\begin{array}{l}\text { Prod } \\
\text { Dev }\end{array}$ & $\begin{array}{l}-1.783+ \\
(1.45)\end{array}$ & $\begin{array}{l}\text { Int'l } \\
\text { Div }\end{array}$ & $\begin{array}{l}-1.477^{*} \\
(2.06)\end{array}$ & $\begin{array}{l}\text { Int'l } \\
\text { Div }\end{array}$ & $\begin{array}{l}-1.381+ \\
(1.31)\end{array}$ \\
\hline $\mathrm{N}$ & 34 & & & & 19 & & 34 & & 12 \\
\hline
\end{tabular}

To recap, our empirical goal was to test the effect of strategy and the sequence of strategies on the performance (measured by survival) of railroads. Using an appropriate technique to control for the availability of resources on the choice of strategy, we have demonstrated that following the hypothesized sequence gives a higher duration of survival relative to remaining. 


\section{BIOS:}

Michael L. Pettus earned his Ph.D. in strategic management from the University of Illinois at UrbanaChampaign. He has published in the Academy of Management Journal and the Strategic Management Journal. His research focuses on the evolution of resources and capabilities over time, and on the positioning of firms after deregulation. For over 40 years, he has worked for, and completed consulting assignments for, many large multinational firms. He has written three books: (1) Growth from Chaos, which explains how firms position themselves after their specific industry has been deregulated; (2) a strategic management text (now in its seventh edition), which has been used in over 95 universities, and (3) a collection of cases, which can be used in strategic management courses.

Yasemin Y. Kor earned her Ph.D. in Business Administration from the University of Illinois at UrbanaChampaign. She is currently the Beckwith Professor of Management Studies at the Cambridge Judge Business School. She studies CEO and executive team competencies (human and social capital), board governance effectiveness (board capital and CEO-board interactions), and strategic change and renewal. Dr. Kor is a former Fulbright research scholar and previously served as an Associate Editor for Journal of Management.

Joseph T. Mahoney earned his Ph.D. from the University of Pennsylvania, with a doctorate in Business Economics from the Wharton School of Business. He is currently the Caterpillar Chair of Business in the College of Business at the University of Illinois at Urbana-Champaign. His research interest is in the area of organizational economics, which includes: dynamic capabilities and resource-based theory, transaction costs theory, real-options theory, agency theory, property rights theory, stakeholder theory, and the behavioral theory of the firm.

Steven C. Michael is currently Professor in the College of Business at the University of Illinois, UrbanaChampaign. He received the Ph.D. in Business Economics from Harvard University in 1993, through a joint program of the Department of Economics and the Harvard Business School. Dr. Michael's research focuses on how innovations are identified and exploited to create new businesses, markets, and organizations. He has won several teaching awards, including the Campus Award for Teaching Excellence, Illinois's highest honor for teaching. Professor Michael also leads student teams on innovation projects for such firms as Abbott Labs, eBay, John Deere, and Boeing. 